apparent between runs 4 and 5 because, owing to technical difficulty, the interval between these was prolonged to 10 minutes.)

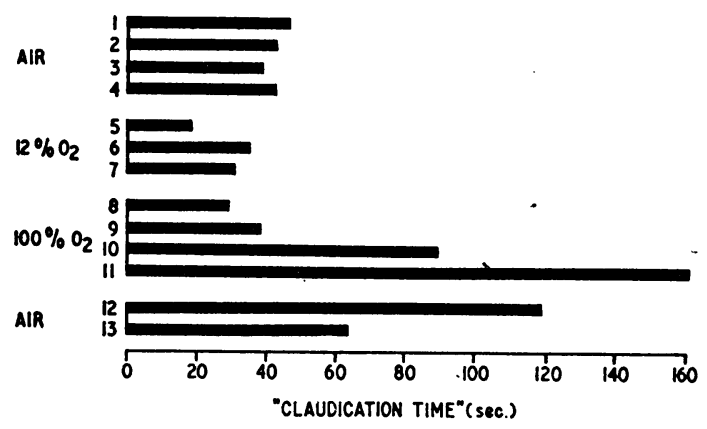

FIG. 3.-Variation of "claudication time" with oxygen content of respired gas (Case 4).

The metabolic rate of peripheral nerves is low compared with grey matter and other tissues, and is probably only about $1 / 10$ of that of muscle weight for weight (Larrabee, 1958). It is established that oxygen uptake of a peripheral nerve trunk in the rat varies directly with the frequency of stimulation (Cranefield et al., 1957). It may be predicted, therefore, that the oxygen tension in the interstices of a nerve trunk will be lowered during exercise if a simultaneous increase in the blood supply through the vasa nervorum is prevented. In this partially anoxic state the condition of the nerve will be comparable with that in the experiments of Lewis et al. (1931) when the blood has been allowed to return to a temporarily ischaemic nerve, the fibres near the blood-vessels being better oxygenated than those further away. In these circumstances sensation of tinglings and "pseudo-cramp" occur, probably due to impulses arising at the site of anoxia in touch-fibres and muscle-afferents respectively (Cobb and Marshall, 1954 ; Nathan, 1958). Thus a relative ischaemia of active cauda equina roots during exercise seems the likeliest explanation of the symptoms in our patients.

\section{Summary}

Attention is drawn to the production of intermittent claudication in four patients by a prolapsed lumbar disk or an arachnoiditis of the cauda equina. The problem of distinguishing such cases from those of aorto-iliac vascular disease, which can give a closely similar clinical-picture, is discussed. The probable mode of production of the symptoms is briefly examined.

I am grateful to Dr. W. Ritchie Russell, Mr. Joe Pennybacker, and Dr. Honor Smith for encouragement and permission to study and report patients under their care ; to Dr. E. H. Porter for technical advice ; and to Miss $\mathrm{M}$. McClarty for diagrams.

\section{REFERENCES}

Blau, J. N., and Logue, V. (1961). Lancet, 1, 1081.

and Rushworth, G. (1958). Brain, 81, 354. 183., and Marshall, J. (1954). Ұ. Neurol. Neurosurg. Psychiat., 17,

Cranefield, P. F., Brink, F., and Bronk, D. W. (1957). F. Neurochem., $1,245$.

DeWeese, J. A. (1960). New Engl. F. Med., 262, 1214.

French, E. B., and Price, W. H. (1962). Brit. med. F., 2, 1290.

Graham, J. R. (1960). New Engl. F. Med., 263, 1273.

Graham, J. R. (1960). New Engl. F. Med., 263, 127

Larrabee, M. G. (1958). F. Neurochem., 2, 81.

Lewis, T., Pickering, G. W., and Rothschild, P. (1931). Heart, 16, 1.

Lewtas, N. A., and Dimant, S. (1957). F. Fac. Radiol. (Lond.), 8, 276

McArdle, B. (1951). Clin. Sci., 10, 13.

Nathan, P. W. (1958). f. Neurol. Neurosurg. Psychiat., 21, 12.

\title{
Treatment of Herpes Simplex Lesions of the Face with Idoxuridine : Results of a Double-blind Controlled Trial
}

\author{
B. E. JUEL-JENSEN,* M.A., B.M., CAND.MED. ; F. O. MACCALLUM, † M.A., M.D., B.SC., M.R.C.P.
}

Brit. med. F., 1964, 2, 987-988

After Kaufman's (1962a) report of successful treatment of experimental herpes simplex keratitis in the rabbit with 5-iodo2 '-deoxyuridine (idoxuridine) and his optimistic report of its value in the same disease in man (Kaufman, 1962b) it was obvious that the possible therapeutic effect of I.D.U. on herpes simplex of the skin should be investigated. Burnett (1962) in the U.S.A. reported no therapeutic benefit, but Hall-Smith et al. (1962), who used a $0.1 \%$ solution applied topically or $0.5 \%$ in an ointment in a small uncontrolled group, thought their patients had benefited. As Luntz and MacCallum (1963) reported less favourably than Kaufman on the value of I.D.U. when it was compared with neomycin ointment in the treatment of keratitis in man it seemed imperative to examine its effect on skin lesions in a double-blind controlled trial. The type of ointment and its source was the same ${ }^{1}$ as that used by Hall-Smith et al. (1962).

\section{Methods}

Recurrent herpes lesions of the face in different patients are of variable duration. They may last from 2 to 20 days, and attacks may occur every few weeks or as rarely as once or twice a year. The history of patients with herpes suggested that the duration of the untreated attack was fairly constant in the individual. It therefore might be possible to measure the efficacy of treatment by the shortening of the duration of the lesion. However, if the patients' estimates of the normal duration of the untreated lesion were relied upon an avoidable error would be introduced into the trial. Verifying the alleged duration by observing untreated attacks in propositi would have taken an unreasonable length of time. We therefore decided to compare the time taken for complete healing in patients who were treated with I.D.U. cream and inactive base.

The patients in the trial were drawn from the staff of the United Oxford Hospitals. Herpes sufferers were asked to report as soon as possible after the onset of the first symptoms, usually prickling and tingling of the skin. A careful history was taken, including the duration of previous attacks. Only patients with

* Hospital Medical Officer, Radcliffe Infirmary, Oxford.

† Consultant Virologist, Radcliffe Infirmary, Oxford.

'Smith Kline and French Laboratories Ltd. 
lesions of less than 24 hours' duration were included in the trial. A swab was taken from the lesion into virus transport medium and the sample was sent to the virus laboratory within an hour. Each patient was given a tube with $5 \mathrm{~g}$. of cream and instructed to use $\frac{1}{2}$ in. $(1.3 \mathrm{~cm}$.) (c. $50 \mathrm{mg}$.) of this six-hourly.

The tubes contained either inactive base or $0.5 \%$ I.D.U. in the same base. The order of the tubes had been randomized and was unknown both to patient and to observer. Each patient was seen daily by the same observer and the appearance of the lesion recorded until it had disappeared completely.

\section{Results}

Of the 27 patients who participated, nine did not fulfil the criteria for successful completion of the trial. One patient receiving the active and two the inactive ointment withdrew because the lesion was far worse than it had been before (on the fourth and the fourth and seventh days respectively). We failed to isolate herpes virus from two patients on active treatment, and from four patients on inactive treatment. Because the diagnosis, though clinically certain, remained in doubt, these patients were excluded from the final analysis of the results. Eleven patients treated with I.D.U. were compared with seven who had received a placebo. These results are set out in the Table. Patient 7 developed herpes in a new site and was admitted once more as a new entrant.

\begin{tabular}{|c|c|c|c|c|c|c|c|c|}
\hline Patient & $\begin{array}{l}\text { Sex } \\
\text { and } \\
\text { Age }\end{array}$ & $\begin{array}{c}\text { Pro- } \\
\text { voking } \\
\text { Factor }\end{array}$ & $\begin{array}{l}\text { Usual } \\
\text { Dura- } \\
\text { tion of } \\
\text { Attack } \\
\text { (Days) }\end{array}$ & Site & $\begin{array}{l}\text { Dura- } \\
\text { tion } \\
\text { in Trial } \\
\text { (Days) }\end{array}$ & $\begin{array}{l}\text { Sub- } \\
\text { stance }\end{array}$ & $\begin{array}{l}\text { Shorten- } \\
\text { ing of } \\
\text { Attack } \\
\text { (Days) }\end{array}$ & $\begin{array}{c}\text { Treat- } \\
\text { ment } \\
\text { Started } \\
\text { after } \\
\text { Onset } \\
\text { of First } \\
\text { Symp- } \\
\text { toms } \\
\text { (Hours) }\end{array}$ \\
\hline 1 & F 31 & $\mathrm{U} / \mathrm{V}$ & 7 & $M T$ & 7 & Active & 0 & $<24$ \\
\hline 2 & F 21 & Cold & 21 & $M \underset{\mathrm{T}}{\mathrm{B}}$ & 8 & Placebo & 13 & $<24$ \\
\hline 3 & M 50 & $\begin{array}{l}\text { Un- } \\
\text { known }\end{array}$ & 14 & M B & 13 & Active & 1 & $<18$ \\
\hline $\begin{array}{r}4 \\
5 \\
6 \\
7 \\
8 \\
9 \\
10 \\
11 \\
12\end{array}$ & $\begin{array}{ll}M & 47 \\
\mathrm{~F} & 21 \\
\mathrm{~F} & 22 \\
\mathrm{~F} & 27 \\
\mathrm{~F} & 27 \\
\mathrm{~F} & 29 \\
\mathrm{~F} & 18 \\
\mathrm{~F} & 29 \\
\mathrm{M} & 52\end{array}$ & $\begin{array}{l}\text { Cold } \\
\text { ", } \\
\text { ”, } \\
\text { ", } \\
\text { Menst. } \\
\text { Un- } \\
\text { known }\end{array}$ & $\begin{array}{c}7-14 \\
7 \\
14 \\
7-21 \\
7-21 \\
14 \\
7 \\
7 \\
4-5\end{array}$ & $\begin{array}{ll}\mathrm{L} & \mathrm{T} \\
\mathrm{M} & \mathrm{T} \\
\mathrm{L} & \mathrm{B} \\
\mathrm{M} & \mathrm{T} \\
\mathrm{M} & \mathrm{T} \\
\mathrm{M} & \mathrm{T} \\
\mathrm{L} & \mathrm{B} \\
\mathrm{M} & \mathrm{T} \\
\mathrm{L} & \mathrm{B}\end{array}$ & $\begin{array}{r}19 \\
8 \\
9 \\
12 \\
7 \\
7 \\
12 \\
9 \\
10\end{array}$ & $\begin{array}{c}\text { Placebo } \\
\text { Active } \\
\text { ", } \\
\text { ", } \\
\text { Placebo } \\
\text { Active } \\
\text { Placebo }\end{array}$ & $\begin{array}{r}-5 \\
-1 \\
5 \\
0 \\
0 \\
7 \\
-5 \\
-2 \\
-5\end{array}$ & $\begin{array}{l}<24 \\
<24 \\
<12 \\
<6 \\
<12 \\
<24 \\
<24 \\
<12 \\
<6\end{array}$ \\
\hline $\begin{array}{l}13 \\
14 \\
15 \\
16 \\
17 \\
18\end{array}$ & $\begin{array}{ll}\mathrm{F} & 20 \\
\mathrm{~F} & 21 \\
\mathrm{~F} & 29 \\
\mathrm{M} & 28 \\
\mathrm{~F} & 50 \\
\mathrm{M} & 50\end{array}$ & $\begin{array}{c}\text { Cold } \\
\text { ", } \\
\text { U', } \\
\text { U/v }\end{array}$ & $\begin{array}{r}7-10 \\
7-10 \\
12-14 \\
3 \\
14 \\
5-6\end{array}$ & $\begin{array}{ll}M & T \\
L & B \\
M & T \\
L & T \\
M & T \\
L & T\end{array}$ & $\begin{array}{l}9 \\
6 \\
7 \\
6 \\
2 \\
7\end{array}$ & $\begin{array}{l}\text { Active } \\
\text { Placebo } \\
\text { Active } \\
\text { Placebo }\end{array}$ & $\begin{array}{r}0 \\
1 \\
5 \\
-3 \\
12 \\
-1\end{array}$ & $\begin{array}{l}<24 \\
<24 \\
<12 \\
<12 \\
<4 \\
<12\end{array}$ \\
\hline
\end{tabular}
U/V=Ultra-violet light. $\quad \mathrm{T}=$ Top. $\quad \mathrm{B}=$ Bottom. $\mathrm{L}=$ Lateral. $\quad \mathrm{M}=$ Midline part

The average duration of the attack was 8.9 days (S.E. \pm 1.325 ) for patients receiving the active cream and 8.6 days (S.E. \pm 0.76 ) for those receiving the inactive cream. If the groups are broken down into those who started treatment less than 12 hours and those who started treatment between 12 and 24 hours after the onset of the first symptoms the figures are 7.7 and 10.4 days for six and five patients on active treatment, and 7.7 and 9.3 days for three and four patients on inactive treatment.

\section{Virology}

Swab extract in $0.1-\mathrm{ml}$. amounts was inoculated into two tubes of primary amnion cultures. When the characteristic cytopathic changes caused by herpes simplex virus were seen the identity of the virus was verified by neutralization tests with specific antiserum. No other virus was isolated. Herpes virus was not isolated from swabs of the surface of early lesions in six of the original 27 patients even when the total $2 \mathrm{ml}$. of transport medium was used, though all were shown to be chronically infected with herpes simplex virus by serological tests.

\section{Discussion}

The trial was interrupted after 27 patients had been treated, and when, in the event, 18 had fulfilled the criteria for final inclusion in the series. On the average the duration of an attack was 0.3 day longer in the patients receiving the active treatment. The duration seemed to be shorter in both groups when treatment was started before 12 hours after the onset of symptoms ( 7.7 days in both) than in those who started the ointment more than 12 hours after the onset of the first symptoms (10.4 and 9.3 days respectively). It appears that, at least with the small numbers available, there is no significant relation between the delay in instituting treatment and the duration of the lesion in treated and control cases.

Although it is by no means proved that the active substance is harmful, these results do not support the conclusion of a therapeutic advantage from the use of I.D.U. cream.

The lesions were all of the skin over the chin, near or on the corner of the upper or lower lip, and in one instance on the nose. Although I.D.U. is active against herpes virus in vitro, it is obviously not possible to get adequate amounts of this relatively insoluble substance into the affected cells by application of a cream to the surface.

The problem of how to get the I.D.U. into intimate contact with the affected cells has still to be solved. It occurred to us that it might be possible to get an effective concentration of I.D.U.-containing fluid into the affected area by using a modified airgun for intradermal injections. Experiments on a number of patients so far have shown a complete change in the natural history of the lesions which do not develop the normal blisters and scabbing, but disappear within the time the entry wound could be expected to take to heal; the normal itching and tingling also vanishes very soon after the injection. This may be a purely mechanical effect, but the method is now the subject of another double-blind controlled trial.

\section{Summary}

Twenty-seven patients with herpes of the face participated in a double-blind controlled trial to test the effect of 5-iodo-2'deoxyuridine (idoxuridine), $0.5 \%$ in cream. Of these, 18 fulfilled the criteria of the trial: 11 were treated with $0.5 \%$ idoxuridine cream and 7 with inactive cream. The active cream was found to have no therapeutic advantages over the placebo cream. An alternative method of application of idoxuridine is discussed.

Our thanks are due to Dr. T. A. Turnbull, of Smith Kline and French Laboratories Ltd., for the supply of I.D.U. and placebo cream ; to Mr. Ivor Chinn for his help with the virus cultures; to Miss Craig and Miss James, of the Radcliffe Infirmary Pharmacy; and to our patients-doctors, medical students, nurses, and other members of the staff-for their intelligent co-operation. We are much indebted to $\mathrm{Dr}$. W. I. Cranston for valuable criticism and suggestions, and to Mr. D. Hewitt, of the Department of Social Medicine.

\section{REFERENCES}

Burnett, J. W. (1962). Quoted by M. M. Tolman, and G. F. Wilgram, Practitioner, 1962, 184, 445.

Hall-Smith, S. P., Corrigan, M. J., and Gilkes, M. J. (1962). Brit. med. \}., 2, 1515 .

Kaufman, H. E. (1962a). Proc. Soc. exp. Biol. (N.Y.), 109, 251.

(1962b). Perspectives in Virology, III.

Luntz, M. H., and MacCallum, F. O. (1963). Brit. F. Ophthal., 47, 449. 